\title{
The Secular Realm as Interfaith Space: Discourse and Practice in Contemporary Multicultural Nation-States
}

\author{
Paul Hedges $(\mathbb{D}$ \\ S. Rajaratnam School of International Studies, Nanyang Technological University, Singapore 639798, Singapore; \\ ispmhedges@ntu.edu.sg
}

Received: 31 July 2019; Accepted: 21 August 2019; Published: 22 August 2019

\begin{abstract}
While classically posited as the separation of religion from public life, it is suggested that the contemporary secular public sphere in multicultural contexts has become a habitat for interfaith dialogue. Looking at dynamics in classical secular theory as well as some recent theorists of secularism and multiculturalism, most particularly Jürgen Habermas, Charles Taylor, Tariq Modood, and Rajeev Bhargava, it is shown that far from being hostile to religion much of the practice of secularism is often entwined with particular discourses of religious norms. Using spatial theory, especially that of Lefebvre, four cameos from the UK, USA, Singapore, and India are used as indicative of the way that interfaith discourse is embedded in various aspects of the secular public sphere from governmental, through official Non-Governmental Organisations (NGOs), to grassroots levels such that as forum externum religion is accepted in this space as interfaith dialogue. It is argued that a conceptual linkage of interfaith motifs is, if not inherent, then at least embedded in the secular realm in the contemporary multicultural context.
\end{abstract}

Keywords: interfaith; interreligious; secularism; multiculturalism; public sphere; Tariq Modood; Henri Lefebvre; spatial; Jürgen Habermas; Charles Taylor; Rajeev Bhargava; dialogue; freedom of religion

\section{Introduction}

The last few centuries have seen Western cultural and political hegemony spread its interpretations of state and society globally. One key framing of the modern nation-state is the secular-religious divide, where each pole in this binary is posited as inhabiting a distinct realm. The secular informs what is seen as the public sphere with its common reason, and disciplines such as the sciences and economics. The religious is imagined as the private sphere where it may govern personal beliefs and morals. It is clear, though, that this ideal-type distinction of the secular-religious divide has not been the standard practice of most nation-states, and the division is commonly breached. Nevertheless, it provides an underlying logic that has often dominated the political, sociological, and philosophical discourse as to how the secular and the religious should operate (Modood 2019a, pp. 1-30). In recent years, and particularly since $9 / 11$, a further challenge to this arrangement has been the extolling of interfaith $^{1}$ dialogue. $^{2}$

1 In some contexts, interreligious is used rather than interfaith. This is often a matter of country-specific usage. While they are sometimes distinguished, such distinctions are inherently unstable. Herein, following typical UK usage, "interfaith" is employed, but it should not be read as in some way stressing whatever "faith" is imagined to be in contradistinction to whatever "religion" is imagined to be, especially when both are coupled with the prefix "intra".

2 Herein, interfaith dialogue is understood broadly as denoting a wide range of practices and interactions between religions, and sometimes between religion and non-religion, that may not fit some typical stereotypes of dialogue-if by this it was envisaged that it involved religious leaders sitting and discussing broadly theological topics. For a discussion of the variety 
Interfaith dialogue, from being a generally private and marginal interest of individuals, has become the concern of governments and civil society more broadly (Brodeur 2005). As such, interfaith discourse has entered the secular realm as an allowable form of religion. In this paper, it is intended to explore how the religious and secular are envisaged with a particular focus on the nexus of interfaith dialogue as a primary site of both contention and consensus, exploring how the secular realm, or the public sphere, has become a key interfaith space. It would be useful at this stage to note what is meant by interfaith dialogue, which in this paper will follow the broad remit of activities often found so defined within interreligious studies. While subject to some critique (see Hedges forthcoming), the well-known four-fold typology of dialogue usefully sums up its broadness (Race 2008, pp. 161-63; Hedges 2010, pp. 60-61): as the dialogue of theological exchange, it encompasses often elite discussions of concepts and theological questions; as the dialogue of life, it relates to the day-to-day meetings in social encounters of ordinary people in their lived experiences; as the dialogue of religious experience, it can include joint activities of prayer, ritual exchange, or learning from meditation techniques in another tradition; and, in the dialogue of action, we find included such things as social cohesion, political activism, and work for community or ecological improvement inspired by shared concerns across religious borders.

I will begin by outlining some key concepts of the division of the secular and religious. This is well-trodden, if often disputed, territory in the literature. As such, my concern will primarily be to draw broad brushstrokes over general agreements, but also explore some of the points of contention. This will show how the seemingly impermeable barrier of the secular and religious has always been unstable and that far from there being a singular conception of the secular, we actually see many secularisms. I will then turn to some recent theorists who have discussed the role of the secular, the multicultural, and the religious in public life. In particular, I will draw from Jürgen Habermas, Charles Taylor, Tariq Modood, and Rajeev Bhargava, which will engage not only different concerns but also some of the global issues that are part of these debates. This will involve an engagement with theories of multiculturalism which, while not the primary concern of this paper, are a contextual part of why much classical theory on secularism has been found wanting. Certainly, multiculturalism provides the context in which the public sphere as interfaith space is framed; in a mono-religious ${ }^{3}$ society, there would simply be no need to frame an interfaith space. These first two parts will provide a theoretical platform for the paper, which will next turn to a more phenomenological and literature-based survey to look at manifestations of the interfaith as part of the public sphere. A comprehensive survey would be impossible in one paper, as such some global and, it is contested, representative samples are given from the UK, Singapore, the USA, and India. These four locations can all, more or less, broadly be termed secular democratic systems, but each working out the relationship of the secular and religious in different ways. As all are countries in which English is the predominant language, it will also allow a comparison of some of the terms and language, notwithstanding the nuances of local usage. Further, they are areas which may have various contestations as to how they negotiate the secular-religious domain. The UK has an established church which is often seen as antithetical to secular principles, but which Modood sees as a fairly common European mode of secularism (Modood 2019a, pp. 146-50, 182-85). Singapore frames itself as a religion-friendly secularism (Hedges and Taib 2019), but is also seen as very hands on and engaging in the direct management of religion in ways that may infringe freedom of religion. ${ }^{4}$ The USA, despite its strict separation model, sees Christianity invoked heavily by politicians and in national life (Domke and Coe 2010). India, meanwhile, while set up as a secular

of activities often included in the rubric of interfaith dialogue, see (Race 2008; Hedges 2010, pp. 59-62). A brief working definition is also offered below.

3 While multiculturalism is contrasted here with a mono-religious context, these are not necessarily distinct. However, within the contexts we are discussing, multiculturalism provides the principle frame in which a multi-religious society arises.

4 Reports on freedom of religion sometimes see Singapore ranked amongst the lowest rated countries on these scales. For the 2013 figures from PEW, for instance, it scored 6.6 (with 10 being the most restrictive), see https://www.pewresearch.org/wpcontent/uploads/sites/7/2015/02/Restrictions2015_byRegion.pdf. 
system which was also "religion-friendly" has seen the rise of right-wing religious nationalism in recent years (Bhargava 1999b, pp. 486-87). As such, while in some ways each is a prototypical or commonly cited example of a secular state, they all show aspects of the diversity found within the actual practice of secularism in the running of a country, and also the rough edges where the theories of the divide of religion and secularism are seen to fray against the hard facts of life (Hedges forthcoming). We will draw this survey together with a look at theories of space and place to show how an interfaith space is found within the public sphere. Some conclusions for theorising both conceptual and practical issues will be addressed to draw the paper to a close.

\section{The Secular-Religious Divide: Theories and Their Failings}

It is generally accepted that secularism rests upon two pillars, or principles, one derived from what is seen as the French model and the other from what is seen as the American model. The former represents what is termed freedom from religion, the latter freedom of religion. Based in the laïcité model, freedom from religion concerns the institutions of the state being separate from the institutions of the church. This was based in the separation of the Catholic Church and governance first adopted after the 1789 Revolution and then in the 1905 Constitution (Caron 2007). That is to say, citizens of the secular state should not be bound by the diktats of priests, bishops, or any ecclesiastical authority. The church or any religious authority should not have a say in how the country is run, how people live their lives, or how laws are formulated. As noted, this is a sociological ideal-type and may not relate to any actual practices, because it is certainly the case that French culture is enthused with Catholic tradition which informs many assumptions about practice and norms (Modood 2019a, pp. 125-26). Meanwhile, freedom of religion draws from the experience of early dissenting immigrants to the Americas who wanted to be able to practice without the state or established church decreeing accepted forms of Christian belief. First around Philadelphia, and then more widely, this was put into practice. It concerns the right to believe, or not to believe, as a personal matter of conscience in which the state should have no say. Again, this is very much an ideal-type, and certainly at first did not extend to the toleration or acceptance of Catholics, while it was only in 1978 that Indigenous Americans found their traditions accepted as religion, rather than superstition, and so included within the remit of freedom of religion (Hedges forthcoming).

As indicated, the two key principles of secularism are problematic in terms of how they may be implemented. While they often operate as accepted norms, how they manifest is another matter. For the purposes of this essay, four further areas of theoretical incertitude or tension may also be highlighted as problematizing the distinction of religion and secularism, in particular in terms of how these two principles may be put into practice.

Firstly, and inherent in what is noted above, is the problematic category of "religion". The category religion can be seen as an essentially contested concept (Hedges 2017a). That is to say, a term which has no clear, distinct, or agreed meaning. Some scholars even suggest that the concept "religion" should be abandoned because we can find no agreed meaning and it has a history based partly on colonial powerplay that has been part of the negotiation of what is, and is not, classed as religion (Hedges 2018b). These questions, to some extent, go beyond our concerns. Whatever the heritage and deficiencies of religion as a term and concept, it is built into the secular-religious divide-which we discuss further below-and is part of the current social reality of twenty-first-century legal and political discourse. However, the important point here is that what gets to count as a "religion" is neither clear nor straightforward, and hence where secularism stands in relation to this is problematic. As noted above, indigenous American traditions were for a long time not regarded as religion, while traditions such as Scientology, Falun Gong, or Wicca are the subject of debate in many jurisdictions; terms such as "superstition", "cult", or others are also part of the classificatory schema that apply to these discussions (Hedges forthcoming). Even if we assume that, in various locations, secularism may be seen as related to whatever is therein envisaged as the "major world religions" (itself a political and suspect term, Masuzawa 2005), this is not stable. American freedom of religion at first extended 
primarily to Non-Conformist Protestants rather than Catholics, while Modood and others have shown that Islam does not always sit neatly in relation to much contemporary secular-religious discourse (Modood 2019a, pp. 75-88; Asad 2003, pp. 159-80; Eade 1996). There is no clear-cut and natural marker as to what "freedom from ..." " or "freedom of ..." actually applies to, and this has always been negotiated and contextually variable.

Secondly, and to some extent extending our first point, is the modern Western context in which the secular-religious divide arises. We, arguably, cannot have one without the other, and so may speak of the co-creation of the secular and religion (Fitzgerald 2007). Within the logic of religion and the secular, while each is often taken as a discrete and isolated entity and sphere, they make sense to some extent only because we have the other. In a medieval or early modern worldview, where the sovereign ruled by the divine right of monarchs, we cannot demarcate one realm of life as secular, because politics, economics, and many other areas fall within what are seen as divine decrees. The two cannot, from within the worldview of the time, be separated. Equally, the modern physical sciences-today discursively paradigmatically secular-only developed because of a deeply theological trust that God's ordering of the world made it rational and subject to investigation (Hedges 2017b). The distinction of the territories of science and religion is another modern and somewhat arbitrary and culturally determined imaginary (Harrison 2015). Elsewhere, and at other times, we would not demarcate the world this way. A modern, Western, and Protestant Christian worldview has given us our modern perception of the secular, and of religion. This is a matter we elucidate further in our next two points.

Thirdly, it has been noted that the modern discourse of both secularism and also human rights, which gives substance to the freedom of religion concept, favours certain forms of religion. The forum internum is favoured over the forum externum (Ferrari 2012). In other words, if religion is a matter of private belief and morals, then, to the state and legal functions of the same, what an individual believes about it and considers correct is entirely a matter outside of its purview (Asad 2003, pp. 185-86). Religion that manifests in private and personalized forms is generally seen as entirely compatible with secularism. This, notwithstanding some of the rough edges we have discussed, is the exact style of religion found in many forms of secularized and privatized Protestantism that have dominated the areas where the discourse of the secular arose. This is seen in conceptualisations like William James' classic work on defining, conceptualising, and mapping religious experience (James [1902] 1985). The essence of religion is seen to be internal, personal, private, and discrete to each individual. It is not communal, enacted, and does not have manifestations in social and political activities. Of course, not all Protestantism ever has or does now conform to this elite representation of another ideal type. But personal and privatized Protestantism is often what the discourse on secularism is framed in relation to. In freedom of religion terms, as a human right, the right to believe is not the point of contention, but where the right to "manifest" beliefs becomes actualised is where we start to see contestation and politico-legal regulation. Importantly, this is one reason why, herein, the spatial aspect is stressed; as religion is manifested, it becomes a matter of spatial contestation and while this is often associated with conflict (Kong and Woods 2016), the manifestation of interfaith dialogue is also a spatial matter within the purview of the geography of religion (Kong and Woods 2016, pp. 3-4). Indeed, it is argued herein that religion as openness to other religions, manifested as interfaith dialogue, is the most acceptable forum externum of religion within the contemporary secular sphere.

Fourth, inherent in what has been said is the Western-centric bias of all this theorising (Amin 2011). The European exceptionalism of much social science theory has long been noted and of course when we say "Europe", we are referring by and large to a number of specific North Western European countries in particular (Alatas 2003, p. 602), with the USA as their intellectual heir. Today, though, theorists have spoken of multiple modernities indicating the way that the world's path into modernity does not simply take one route-that posited upon the European example-but is diverse and pluriform (Smith and Vaidyanathan 2011; Eisenstadt 2000). Hence, we may speak of secularisms, rather than secularism, and globally we see secular principles being put into operation in various ways (e.g., Cady and Hurd 2010; Bubandt and van Beek 2012; Burchardt et al. 2015; Bhargava 1999a). Whatever the 
case, theorising secularism, secularisation, and the secular-religious divide today cannot be done with reference only to Western examples which have no claim on normativity in a globalised world (Calhoun et al. 2011; Davie 2018).

The classical theory on the secular-religious divide, despite seemingly having neatly packaged the world such that it was regarded as a "dead" question-having supposedly been definitively determined-actually has numerous aporia and fault lines within its conceptualisation (Modood 2019b). Those that have been laid out here provide evidence, for the purposes of this paper, that the secular-religious divide is neither simple nor straightforward. I turn now to four recent theorists who have started to dig into this question and have raised significant points that demand attention in thinking through ways that the secular public sphere may be conceived as an interfaith space.

\section{Four Contemporary Theorists of Secularism, the Public Sphere, and Multiculturalism}

Here, we address our four theorists: Jürgen Habermas, Charles Taylor, Tariq Modood, and Rajeev Bhargava. Notably, given the limits of space, there will be no attempt to comprehensively review the entirety of their work. Rather, specific and strategic aspects of the work of the various theorists, which directly overlap with the concerns of this paper, will be highlighted.

Habermas is one of the most widely cited theorists of secularism and conceptualised that part of it that we term the public sphere (Habermas [1981] 1986). In Habermas' case, our selected concern is the secular framing of the public sphere and the changes that can be seen between his early and his later work. Unlike many theorists, Habermas has performed a dramatic and clear about turn in his own theory, admitting that his earlier work was wrong (Portier 2011). This concerns the place of religion in the public sphere. His earlier work, which may be said to represent a strong classical secularism, was clear that the public sphere should be free of all religious commitments-it was a neutral and value-free sphere of common reasoning founded very much on Enlightenment, public, rational, and secular principles (Habermas [1981] 1986). In this framing, there could be no way that commitments of the supposedly pre-modern, private, irrational, and religious sphere could have a legitimate voice. However, in his more recent work over the last couple of decades, Habermas has acknowledged that the public sphere, being a place where people bring their moral reasoning and values, simply cannot be freed from religion in such a starkly demarcated way (Habermas 2002; Habermas 2008). Our political commitments, often learnt in families or through some tribal-like commitment, can make no greater claim to rationality, and are often based on subjective values, moral commitments, and claimed certainties. In line with a figure such as John Rawls (Rawls 1993), Habermas may be said to represent a new sensibility in political and social theorising that sees that religion can be part of the public sphere. As has been noted already, the secular-religious divide is inherently unstable and contextual, and as such Habermas is in some ways simply acknowledging some problems already noted.

Taylor's thought has been characterised by Modood as part of a Canadian tradition which is very much elite and top-down theorising on multiculturalism and secularism (Modood 2019a, p. 11). In acknowledging the problem of minorities in modern Western states, Taylor has been concerned with how minorities can be accommodated; accommodation being the primary term within the Canadian context to discuss these debates (Beaman 2012). However, it is very much Taylor's monumental $A$ Secular Age which I will draw from here (Taylor 2007). Even before this work, Taylor had spoken about what he terms the great "disembedding" in which modern societies moved away from their more cosmological roots towards an individualism (Taylor 2004, p. 50), which can be likened to Max Weber's notion of disenchantment (Lassman 2004). Taylor, in one of the most in-depth explorations of secularism, argues that having separated God from the spheres of politics, that our secular age then proceeds to make the hypothesis of a deity move from being central to being just one worldview amongst others (Taylor 2007, pp. 12-14). In other words, it becomes an option, but, moreover, it becomes an increasingly dismissible viewpoint. Taylor argues that this is because its rationale is in some transcendent sphere and so distinct from the perceived rational, objective, and empirical basis upon which we share a common space. Taylor perceives this largely negatively and speaks about the 
"flatness" of modern secular society where there is no higher viewpoint or standards and so personal taste becomes the arbiter more than appeal to any "transcendent" reality (Taylor 2007, pp. 728-37). However, and importantly here, is that Taylor argues that modern secularism does not describe the world as it is, but rather tells one story about the world. Indeed, he argues that this narrative has run its course and posits that we are moving towards what Habermas has termed a post-secular age (Habermas 2008). This is not a term I will use, as secularism is embedded in constitutions around the world and shows no signs of budging. Indeed, a problem with Taylor's account is the sense that secularism is only what he perceived in certain Western countries; he does not take other global variations, or even the variety of secularisms in the West, into account. Further, both Habermas and Taylor seem to speak to an ideal-type secularism rather than secularism as practised. As we will see with our next theorists, secularism can be envisaged in multiple ways.

Modood makes an argument which I do not find entirely convincing, but which is nevertheless insightful and will help us draw out some further issues. Modood contests the classical theory, outlined above, arguing that there are not simply two principles of secularism: the French and the American. Rather, he argues, that while both of these two are based upon a principle of disestablishment, much of Europe demonstrates what he sees as a third secular principle of religious establishment that is compatible with religion, what he terms "moderate secularism" (Modood 2019a, pp. 145-61). For instance, the UK has an established church, Germany collects church taxes through the government, and until recently this also operated in Sweden. Every country in the European Union, furthermore, either supports Christian schools or teaches Christianity in its school system, and this includes France (Stepan 2011, p. 117). We cannot, with any coherence, he argues, suggest that the UK, Germany, and Sweden, amongst others, are not secular states; indeed, they are often seen as paradigmatically secular (Modood 2019b). He argues, therefore, that we also see a religion-friendly establishment-based secularism. I believe that the details of his argument are correct, and that he establishes a key point that establishment and secularism are not incompatible, which is certainly contrary to the laïcité principle if taken in a hard sense, or as expressed in the US context in how freedom of religion is codified in the First Amendment: "Congress shall make no law respecting an establishment of religion, or prohibiting the free exercise thereof." However, these secular states—where we see establishment-operate, I would argue, on the same two principles: freedom of religion and freedom from religion (Hedges forthcoming). In Germany, for instance, one can opt out of the church tax system, while religion per se does not impose any laws or burdens on the citizens. That bishops, in the UK, sit by right in the House of Lords is not in itself an imposition of religious law as they are but a small faction within that chamber, notwithstanding some controversy on certain bills where they have swung tight votes relating to what are seen as ethico-religious concerns. Further, I believe, Modood shows considerable variety within the exact application and interpretation of the two principles of secularism (Modood 2009). Indeed, to suggest that both the French and US systems are inherently anti-religious, and that the European example gives us a religion-friendly system, is I think belied by the close association of religious language and lobbies in the US, and again what has been seen as the Catholic bias in the French system. Certainly, in terms of a multiculturalism, the UK may be seen as in many ways more secular than France in that the principles of secularism are not, as Modood and others see them, weaponised against Islam to some degree (Modood 2019a, pp. 75-88). However, the treatment of particular religions is not our concern. Importantly, therefore, what Modood brings to light is two things. First, that secularism can be in line with establishment, but also and importantly that it can be religion-friendly in terms of the two central principles of "freedom from" and "freedom of". Second, that within a multicultural context, and this draws out further what we noted above in terms of problems with the theory of the secular-religious divide, secularism can favour or disadvantage certain religions depending upon how it is operationalised. In particular, an established culture or majority can become a base norm against which the values and needs of others are judged (Modood 2019a, 2019b).

Bhargava, our final theorist, differs in the contextual operation of his work from the other three theorists. All four have been based in Western contexts and primarily theorising the way that a secular 
and multicultural system should work there. Bhargava's context is India and looking to some extent more widely at an Asian theory (Bhargava 1999b). There is a danger, though, in this demarcation between what has been termed the West and the rest. After independence from Britain in 1949, India developed itself as a secular and democratic nation-state and so very consciously drew upon the norms of Western political theory and statecraft developed over the previous few hundred years. It kept its civil service, a legacy of the Raj but which had been learnt from the Chinese as a tool of governance for an empire by the British. Hence, we should not imagine either a clear distinction of Western norms and other global practices, nor to see the global dominance and spread of Western political practices as something developed from some pure imagined Western inheritance (e.g., Clarke 1997; Hobson 2004). However, this is not the place to enter these debates, but it is an important note when we talk about the Indian practice of secularism. One of Bhargava's key arguments is that the Indian form of secularism differs from that of the West because it is religion-friendly (Bhargava 2006). Modood takes exception to this and argues that Bhargava's argument is flawed because he only sees Western secularism as based upon the two classical principles and does not realise that there is the form of "moderate secularism" he identifies (Modood 2019a, pp. 147-48; Modood 2016). There is some merit in Modood's rebuke. The two principles in Western contexts need not be hostile to religion. However, this does not mean that Bhargava has not highlighted a rather different system in India, one where the secular system sees no need to push back against religion and to see it as an essential good in the public sphere (Bhargava 2016). This is not, though, antithetical to the Western experience. However, it operates in a distinct way. Moreover, it shows, as does Modood, that the two main principles can operate in ways which are not hostile to religion, with the principles of freedom of religion and freedom from religion posited in Indian secularism (Bhargava 1999b). Although Bhargava suggests that it is a distinctive Indian way of doing secularism, which contrasts with the Western model, Modood accurately shows there is no single Western model.

\section{Concepts and Cameos}

It is now quite well established that the modern secular nation-state does not, necessarily, reject manifestations of religion in the public sphere, although it favours the forum internum over the forum externum as noted above. However, in recent years, one particular form of religious manifestation has proved particularly attractive to the secular state and may almost be said to be an officially approved form of manifestation: interfaith dialogue (Brodeur 2005; Hedges 2018a; Hedges and Taib 2019; Weller 2009). Indeed, in many ways, it seems to be manifesting as an aspect of how secularism sees itself. To be secular means, almost by default, to be in favour of interfaith dialogue.

Now, two serious caveats need to be noted here. First, it is not to say that every advocate of secularism favours the interfaith motif. For some, religion itself is a harmful bane on society. While we do not typically see this in scholarly discussion on secularism, it has in many Western nations been a part of the public discourse through what are often termed the New Atheists (Beattie 2008). We need not detain ourselves of the utility or applicability of the "New Atheists" epithet for those so described (Hedges 2017b, p. 96), but it is certainly the case that many strongly polemical and anti-religious sentiments have been a part of public discourse and have shaped attitudes. Nevertheless, even here, we still see a distinct rejection of certain forms of religion, and an acceptance of other forms as less baneful. This, within the UK context, is typically stated in terms of Islam being seen as less acceptable, even harmful, while the Church of England is seen as watered down and to some extent more benign. Indeed, its tolerance for other points of view, including other religions (typically in New Atheist polemics being seen as a sign of it not really being properly "religious", i.e., fanatical, as they see it) means that religion which embraces an interfaith ethos is seen as "better" religion (Osborne 2018; Khalil 2017; Modood 2016, p. 196). Second, as far as I am aware, there is no major theorist of secularism who has stated that interfaith dialogue is part of the secular package. Herein, while we have looked at various theorists, none of them sees interfaith dialogue as good per se within the 
public sphere, although it is arguably something that could be said to be implicit within at least some arguments advanced.

Another important issue is that, as may well be clear in what has been said, that in speaking about the secular realm as an interfaith space, our focus is not on actual physical manifestations of places (though these may exist), but on space as a metaphorical and conceptual place. It is what Yi-Fu Tuan labels "mythic space" (Tuan 2008). It concerns the realm of what we may term symbolism, discourse, and perception, although this concerns directly, in this context, behaviour and actions with physical space. I argue that where religion as forum externum may be acceptable behaviour in the public sphere is where it manifests as interfaith dialogue.

We will offer four brief cameos of the secular nation-states we have mentioned above, the UK, the USA, Singapore, and India, to show that manifestations of acceptable religion in public take on the character of an interfaith dialogue, but-and more importantly—the public or secular sphere becomes the realm of the interfaith. This latter part is because, notwithstanding that for a good number of traditions their buildings may be places where interfaith encounters may occur, it is more typically in shared public spaces that interfaith encounters take place. Moreover, even when events occur within a church, mosque, temple, gurdwara, synagogue, or other site it, to some extent at least, ceases to be a site for a particular internally referencing community of practice and becomes a site opened to and welcoming of the wider public. This is not to say that there is a strict demarcation between various places of worship, or communal religious gathering places, and public space. They may overlap. Especially in places such as hospitals, airports, or educational institutes, what may be termed chapels, prayer rooms, or quiet spaces can be intentionally public and multifaith, even if originally designed for one community. Where many religious buildings stand in relation to theory on public space is itself a question worth asking, often they are not private/family nor state/government sites, yet do not quite fit into the broadly conceived secular public sphere as sites for all in the way that museums, hospitals, shopping centres, parks, and other such places do. However, though noting this, we shall not develop this particular line of enquiry here.

Cameo 1: In the document from the UK government's Department for Communities and Local Government, Face to Face and Side by Side (FtF), the public sphere was explicitly advocated to be an interfaith space (DCLG 2008). Stemming from the so-called New Labour administration in 2008, FtF set out an agenda seeking to persuade local governments to engage with various faith communities as part of their work. Moreover, it extolled interfaith activity as something to be supported by the government. Very directly, therefore, it made a predominantly secular (with the caveats we have noted above about the UK as an establishment secularism) government a direct sponsor of interfaith dialogue and saw it as part of its remit (Hedges 2018a). This is, of course, not unique. Patrice Brodeur noted how, in the febrile post-9/11 atmosphere, interfaith moved from the "margins" to the "centre" of power and became noticed by governments, civil society actors, and others (Brodeur 2005). However, this is a very direct manifestation of this in a government document.

Cameo 2: In the USA, Eboo Patel helped spread the Interfaith Youth Core (IFYC) across university campuses and other places (Vecchio and Silverman 2018). Notably, Patel was also part of "The President's Interfaith and Community Service Campus Challenge," a project under the Barack Obama administration from 2011 to 2016, which involved a wider set of partners (see White House n.d.). Part of the manifestation and enabling for this is the acceptance of its programmes under the remit of student welfare programmes within universities, while university presidents and managers have promoted and encouraged these programmes (Vecchio and Silverman 2018, p. 53). The US higher education system is split between private and public institutions, so it is very much the latter that is of particular interest because here the strict separation of church and state operates such that the promotion of religion is prohibited. Yet, even within this context, the validation of interfaith as an aspect of what may be encouraged for public benefit is notable (Peace and Rose 2018; McCarthy 2007).

Cameo 3: The Interreligious Organisation of Singapore (IRO), founded in 1949, is probably the world's second oldest still extant interfaith organisation (Hedges and Taib 2019). Like the Indian 
context advocated by Bhargava, Singapore vaunts itself as having a religion-friendly secularism which contrasts with what it sees as a Western model (Hedges and Taib 2019). Indeed, the IRO, while a Non-Governmental Organisation (NGO) unconnected to government, is often brought onto the public stage for various civic events where it is seen to show the multicultural harmony that prevails (ideally and by design) in that nation-state. For instance, in blessing stations on the Mass Rapid Transport (MRT) system, blessing the Formula One racing track before the annual race, and in saying prayers for officers passing out after training, the IRO if not ubiquitous is certainly a regular fixture to showcase the interfaith nature of social harmony as officially presented. Moreover, in 2019, Singapore organised the first International Conference on Cohesive Societies, under the auspices of the country's president and the Ministry of Culture, Community, and Youth, which saw a commitment being publicly made by religious leaders, and signed by many more, stating their commitment to an agreed and stipulated interfaith bonhomie (Zaccheus 2019).

Cameo 4: In the Indian context, Muthuraj Swamy has been extremely critical of the way that dialogue is often conducted by elite organisations who impose presumptions of religious differences (Swamy 2016). In his fieldwork in Southern India, Swamy noted that ordinary people were not aware of the Tamil term for interfaith dialogue: "Palsamaya Uraiyaadal" (literally, "multireligious conversation") (Swamy 2016, p. 165). Further, in the villages, the use of the markers "Christian", "Hindu", or "Muslim" was not normal, and Swamy found that these were imposed by himself as a researcher (Swamy 2016, p. 170). Rather, what he terms both "[m]ultiple group identities and intra-religious identities" were normative at the grassroots (Swamy 2016, pp. 165-70, 173). He sees what we may term interfaith dialogue amongst such groups as being more organic or "spontaneous", asserting that: "Multiplicity is part of everyday life" (Swamy 2016, p. 174). As such, he is very critical of the discourses of what he terms "elitist" dialogue organisers, who he argues neglect, or even deny, the actual interactions that occur between people (Swamy 2016, pp. 145-60). The kind of ritual sharing and discourse which already occurs is, he believes, what elite dialogue organisers believe they must impose (Swamy 2016, pp. 175-76). Further, he notes that the terms and concepts employed by elite interfaith dialogue practitioners do not resonate with ordinary people (Swamy 2016, p. 165). While he does not seek to "romanticize the experiences of people at the grassroots," Swamy argues that they already have the resources for dialogue inherent in their traditions (Swamy 2016, p. 179). This, he places into a context where religion's relationship to secularism is ambiguous (Swamy 2016, p. 189). Importantly, also, Swamy disputes the claims of some proponents of interfaith dialogue that their work is promoting peace, which may be seen as a legitimate secular end, because they simply perpetuate a "myth" that conflicts are at roots about "religion" (Swamy 2016, p. 125), whereas socio-economic or village identity matters are often at stake (Swamy 2016, pp. 170-73); however, Swamy does not deny that some conflicts are related to claimed religious identities. Nevertheless, the key is that interfaith dialogue work often represents itself as, Swamy argues, imposing religious identities in the claimed pursuit of peace, while it can be framed in a secular context in which respect for all religions is upheld (Swamy 2016, p. 34).

Now, it should be noted that this is not to say that every public manifestation of religion in these countries is interfaith dialogue. In the UK, the established position of the Anglican Church in England and its relation to the monarch means that a coronation is framed in Anglican terms-of course, with Elizabeth II as the country's longest ruling monarch, there has not been one for many decades and the world is very different from 1952, while Prince Charles the heir once spoke of his desire to be a "defender of faith" rather than "defender of the faith" (Sherwood 2017). Moreover, representatives of other religions are often seen at major public events. In the USA, President Trump has surrounded himself by exclusively Christian pastors for various public blessings (Bailey 2017). Yet, this may be seen as going against a trend that saw Obama bring together religious leaders who were not only Christian at public events (Chaddock 2009). In India, the rise of the Hindu right-wing and its Hindutva ideology under President Narendra Modi has challenged the more multifaith framing of the nation that was the legacy of figures such as Gandhi and Nehru (Bader 2015). As such, the current retrenchment may be said to go against a longer history and tendency. Perhaps Singapore, out of all of these, is the only 
country to truly manifest something close to a state neutrality and non-favouritism of any religion, and so to be the most representative of what may be an idealised secularism in this sense. Indeed, the bringing together of assertions of a singular religious identity may also be seen to be a statement against a wider multicultural or interfaith trend in all of these societies. The examples noted, therefore, do not entirely undermine the thrust of this argument. Moreover, there is sometimes a specific framing of context and events behind this.

These cameos, and taking the caveat noted above, are certainly not a demonstration that interfaith dialogue is the only accepted form of public religiosity within these countries or any secular context. Nevertheless, the argument of this paper is that within the current governing logic of the secular space, interfaith dialogue is regarded as the paradigmatic instantiation of what religion is seen to involve as forum externum in relation to its place in the sphere of secularism. This, we have seen, may be promoted by governments. It may be an acceptable form of public promotion of faith commitments in a context where this is not normally permitted. It may also be a signal of the interfaith harmony of traditionally multicultural and multireligious societies. Two very pertinent points must also be noted here. First, as seen within the definition of dialogue, it is not simply a "religious" activity unrelated to "politics" (this conception is especially prevalent when the imagined contrast of religion and secular as inherently distinct is in place), because all religious activity is about contestation in some form. Religion is inherently political (see Hedges forthcoming). Second, it may be asked why it has become permitted by the "secular"/political authorities. It is beyond the scope of this paper to answer this. However, what I believe is that some implicit hints are given herein, of which I will note two. On the one hand, seen in our four case studies, is a concern with social cohesion, which as Brodeur has noted has brought religion (or, most specifically Islam) to the forefront of public and political concern post-9/11 (Brodeur 2005). On the other hand, there is a perception of what "acceptable religion" should look like within a diverse multicultural context. As argued herein, the secular and religious have not normally been distinct. Hence, the appearance of interfaith dialogue as "acceptable religion" is not a breach of some clear boundary, but a new continuation of the manifestation of religion within the realm of the secular.

\section{The Spatial and Interfaith Dialogue}

As mentioned above, it will also be useful to focus on interfaith space as a manifestation of mythic and symbolic forms of space. Our focus here is on, following Henri Lefebvre, "the production of space" (Lefebvre 1991). Summing up the approach that has developed from Lefebvre's pioneering work, Dorren Massey has noted:

The spatial is socially constituted. "Space" is created out of the vast intricacies, the incredible complexities, of the interlocking and the non-interlocking, and the network of relations at every scale from the local to the global. (Massey 1993, p. 155)

This is, using Tuan's term, why we term it "mythic", because we see space created through discourse and human meaning making. The conception of secular space may, variously, tell stories about us as a society, narratives that hope to persuade, coerce, and convince us, or else give portrayals that develop from a society concerning its own self-understanding and self-representation. These need not be distinct. The act of representation and the act of persuasion of one's own self-understanding may go together. Further, when we talk about the secular realm, we see traditions and narratives that have grown up over the centuries-it is no tabula rasa onto which we can place meanings. In this sense, understanding the secular public sphere as interfaith space may be likened to synchronic analysis. While conceived as a way to explore particular physical sites, where we see many narratives built up over generations, it applies symbolically to the secular space. In the mythic imaginary of secular space, there are many contested narratives of what it means, and these are entwined and embedded in such areas as the memories, laws, customs, and spaces (physical and conceptual) that frame it. Kim Knott usefully summaries what a synchronic site denotes: 
Synchronous spaces contain the past within them. An English cathedral may, for example, be situated on an early pre-Christian or Christian site, and may contain within its fabric many phases of building. Its texts, whether monumental, memorial, or manuscript, may add other historical traces, as do its ritual and spatial traditions. Both de Certeau and Lefebvre remark on this, the former writing of "stratified places", the latter of an "etymology of locations". (Knott 2005, p. 33)

As such, a synchronic understanding will underlie our approach. Indeed, this in part will explain why we gave the caveats above on the presence of various mono-religious narratives that also inhabit the space. We do not speak of one narrative, but many narratives laid down, and still being laid down, often in competition with each other. Lefebvre noted that our social spaces "can in no way be compared to a blank page" because they are already "if anything, 'overinscribed" with "multifarious and over-lapping instructions" (Lefebvre 1991, pp. 142-43). To help frame our approach here, we will employ Lefebvre's threefold categorization of how space is experienced. He speaks of "representations of space", "spaces of representation", and "spatial practice". However, I will employ them here partially renamed following a framework that has been outlined elsewhere (Hedges forthcoming). This relates partly to a demarcation made in some scholarship between "space" to speak of extended and generic physical realms, and "place" to speak of those to which we imbue meaning through specific narratives, events, and myths. I will set out below briefly the three categories that we employ following Lefebvre.

Firstly, hegemonic space (Lefebvre's representations of space) is the world created and largely given by hegemonic authorities. This may be governmental, planners, architects, or others, recognizing that most people have little control over their own physical environment. This is also true of our symbolic environment which marketers, religious leaders, politicians, social media influencers, or media moguls may dominate; each variously more powerful depending upon the location. It is seen as largely universalized and impersonal, echoing Marc Augé's work on non-place (Augé 1997, p. 77). Secondly, places of representation (spaces of representation) terms the way that we interact with and give value to the world around us-our living and interaction with the space around us, by which we give symbolic value to locations. This may be the work of oppressed groups against hegemonic space as given to us. Lefebvre saw this as often relating to places heavily invested with symbolic meaning such as graveyards but can refer more generally to any places we invest with significance. Thirdly, spatial practice emphasises the forms of life, behaviour, and practice that we embody within places. It can relate to how we operate within the dictates of hegemonic space, for instance, how we operate in the commute to work, when queuing for our needed paperwork at government offices, but may also be about the way that we inscribe some spaces as place, and give meaning to it. Notably, in Lefebvre's original Marxist theorising, this was very much about the contestation of the proletariat against the practices of the elite and bourgeoise who prescribe space. However, we need not posit this as only a class-based contestation (notwithstanding that this may be part of it), with issues of gender, race/ethnicity, and others being part of this. Moreover, parts of the elite and parts of the non-elite may promote similar agendas against other parts of the elite and other parts of the non-elite. This may indeed be the case with any advocacy of interfaith dialogue within the secular public sphere. Indeed, here the question of contestation will be placed to one side, which places the current usage of these terms somewhat aside from Lefebvre's original systematisation. I will rather seek to show how these may help us to see the interfaith motif as an acceptable and even normative part of current representations of the secular public sphere.

As Elizabeth Harris points out, Lefebvre and other theorists focus on the issue of conflict and tension as part of the negotiating space (Harris 2018). This is inherent in what we have noted, with hegemonic space seeking to impose its discourse on others. In the cameos presented, this can be seen in various ways in which governmental or other official agendas may be drivers of interfaith dialogue. Particularly in the Singaporean context, presentations of interfaith cohesion are what is seen as accepted and normative in terms of religious presence in the public space (Hedges and Taib 2019). 
However, in many secular nation-states, it contests with more mono-religious traditions and those which see secularism as pushing back against religion. However, a religion which is broadly tolerant, if not accommodating of other traditions, is seen as the expectation in a text such as FtF.

Places of representation speak to the ways that non-elites inscribe meaning onto places, which can be seen in our Indian cameo where grassroots actors already have a recognition of religious diversity, but which to become acceptable or recognised sees elite practitioners of interfaith dialogue trying to dictate their own prescription of acceptable interfaith dialogue over this. Again, in the USA, the IFYC is a grassroots organisation that has been able to dictate, to some degree at least, the nature of university campuses in seeing interfaith as a common good within the public sphere.

In terms of spatial practice, the activity of shaping activity in the public space is significant. This paper has not, given the limits of space, entered into the specific practices and activities of interfaith groups, activists, and official organisations, though these are well documented elsewhere (e.g., Halafoff 2013; Race 2008). Rather, the concern has been more conceptual, and it is noted that manifestations of religion as forum externum which fit within the remit of interfaith dialogue can be acceptable within secular spaces. The encouragement and acceptance of this is seen in the pages of a document such as FtF as well as in the public activities of a group such as the IRO, where public multifaith blessings have symbolic resonance. Harris also notes, echoing Tuan, that where religion is concerned, the "mythical" aspects of spatial configuration and narratives are important (Harris 2018). It may be contended here that this is equally true of secular spaces, and that in many contexts the mythos of the public sphere is embodied in acceptance of interfaith bonhomie as accepted and valid forms of religiosity. Modood told us that secularism is not inherently opposed to religion, even established religion, and in its spatial manifestation, the modern secular public space is most conducive to the manifestation of religion as interfaith dialogue. Again, Bhargava's notion of a potential religion-friendly form of secularism may increasingly be posited as based upon a religion that is attuned to, or manifests, the interfaith motif. More exclusive forms of religiosity seem less in accord with the contemporary mythos of the secular public sphere. This, notwithstanding, as noted above, includes some pushback and counter currents which exert forms of more exclusive, often ethno-religious nationalism, in the public sphere. These may, though, also be framed as in some ways hostile or damaging to the modern norms of democratic secular political expectations and so are potential grist to the mill of the argument contained herein.

\section{Conclusions}

Secularism has traditionally been portrayed as, in some ways, antithetical or opposed to religion, but the theorists and examples discussed here demonstrate that this supposition is far from correct. Secularism, and the two principles of freedom of religion and freedom from religion are not, inherently even opposed to some weak forms of establishment. A religion-friendly secularism cannot simply be theorised but is an actuality. Indeed, increasingly within multicultural polities, even those traditionally dominated by one religious tradition, the question of the cohabitation of these religions comes to the fore. It has been argued herein that this means that the secular public space has increasingly become a site in which interfaith dialogue has become the accepted religious norm. For obvious reasons, this has not been illustrated across countries with any depth, and rather the argument has relied upon some selected brief cameos from both Asian and Western contexts as well as a more conceptual analysis of the concept of the public sphere as an interfaith space. Some counter evidence has also been noted. Importantly, though, this counter evidence does not necessarily overturn the argument advanced, because it may be posited to be, in part at least, based upon what may be seen as a backlash and resistance to secular norms embracing interfaith dialogue within a multicultural public space. Space does not permit us to enter this debate here. However, resonances with some contemporary political and social concerns may be apparent to the reader, and this in turn may inspire further research and reflection. The analysis has relied strongly upon a particular reading of Lefebvre's work with various layers of discourse and practice noted. Within this, the argument has led to positing that interfaith dialogue is accepted within the secular realm in a way that other forms of religious activity are not. The 
argument is not intended as a normative claim of what secularism means. However, it is not simply empirically descriptive both because we have noted that there are various conflicting conceptions of how secularism should operate and because we see counter narratives. Rather, it aims to provide a reading of the contemporary discourse of the secular. Within the modern secular nation-state that accepts a multicultural component to its ethos, interfaith dialogue as defining of the public sphere seems inherent in how secularism will be envisaged and practiced. This does not provide, again, any norm for practice because, as we have noted, secularism has never had any single norm but has always been locally and contextually dependent and varied. However, it may be posited that alongside freedom of religion and freedom from religion, secular spaces now often have an implicit third principle which is freedom to be open to religion, i.e., performing interfaith dialogue. Whether this third principle of "openness to" is widely accepted as a third principle alongside "freedom of" and "freedom from" remains to be seen. Importantly, in this paper, the spatial aspects of this have been noted because to simply accept interfaith dialogue, or not, is part of the forum internum, which does not, generally, intersect with secular principles. Rather, it is in the active spatial manifestation of this as forum externum that it becomes involved in wider public discourse as to what is and is not acceptable. We, therefore, see an expectation of interfaith dialogue in the secular public sphere, which we may speak of as an openness to religion and most specifically as an openness to interfaith dialogue, where the manifestation of religion posited within the notion of freedom of religion is to be found.

Funding: This research received no external funding.

Conflicts of Interest: The author declares no conflict of interest.

\section{References}

Alatas, Syed Farid. 2003. Academic Dependency and the Global Division of Labour in the Social Sciences. Current Sociology 5: 599-613. [CrossRef]

Amin, Samir. 2011. Eurocentrism: Modernity, Religion, and Democracy: A Critique of Eurocentrism and Culturalism, 2nd ed. Cape Town: Pambazuka Press.

Asad, Talal. 2003. Formations of the Secular: Christianity, Islam, Modernity. Stanford: Stanford University Press.

Augé, Marc. 1997. Non-Places: Introduction to an Anthropology of Super-Modernity. London: Verso.

Bader, Veit. 2015. Religious Political Parties in Europe and India. In Secularism, Religion, and Politics: Europe and India. Edited by Péter Losonczi and Walter Van Herck. Abingdon: Routledge.

Bailey, Sarah Pulliam. 2017. Photo surfaces of evangelical pastors laying hands on Trump in the Oval Office. The Washington Post. July 12. Available online: https://www.washingtonpost.com/news/acts-of-faith/wp/ 2017/07/12/photo-surfaces-of-evangelical-pastors-laying-hands-on-trump-in-the-oval-office/?utm_term= .5a47819f4be2 (accessed on 22 August 2019).

Beaman, Lori, ed. 2012. Reasonable Accommodation: Managing Religious Diversity. Vancouver: University of British Columbia Press.

Beattie, Tina. 2008. The New Atheists: The Twilight of Reason and the War on Religion. Maryknoll: Orbis Books.

Bhargava, Rajeev, ed. 1999a. Secularism and Its Critics. Delhi: Oxford University Press.

Bhargava, Rajeev, ed. 1999b. What is Secularism For? In Secularism and Its Critics. Delhi: Oxford University Press, pp. 486-542.

Bhargava, Rajeev. 2006. Political Secularism. In The Oxford Handbook of Political Theory. Edited by John Dryzek, Bonnie Honnig and Anne Phillips. Oxford: Oxford University Press, pp. 636-55.

Bhargava, Rajeev. 2016. Is European Secularism secular enough? In Religion, Secularism, and Constitutional Democracy. Edited by Jean L. Cohen and Cécile Laborde. New York: Columbia University Press, pp. 157-81.

Brodeur, Patrice. 2005. From the Margins to the Centers of Power: The Increasing Relevance of the Global Interfaith Movement. Cross Currents 55: 42-53.

Bubandt, Nils Ole, and Martijn van Beek, eds. 2012. Varieties of Secularism in Asia: Anthropological Explorations of Religion, Politics and the Spiritual. London: Routledge.

Burchardt, Marian, Monika Wohlrab-Sahr, and Matthias Middell, eds. 2015. Multiple Secularities Beyond the West: Religion and Modernity in the Global Age. Berlin: De Gruyter. 
Cady, Linell, and Elizabeth Hurd, eds. 2010. Comparative Secularisms in a Global Age. Basingstoke: Palgrave-Macmillan.

Calhoun, Craig, Mark Jurgensmeyer, and Jonthan Van Antwerpen, eds. 2011. Rethinking Secularism. Oxford: Oxford University Press.

Caron, Nathalie. 2007. Laïcité and Secular Attitudes in France. In Secularism and Secularity: Contemporary International Perspectives. Edited by Barry Kosmin and Ariela Keysar. Hartford: Institute for the Study of Secularism in Society and Culture, pp. 113-24.

Chaddock, Gail Russell. 2009. The role of religion under Obama. The Christian Science Monitor. January 22. Available online: https://www.csmonitor.com/USA/2009/0122/p01s02-usgn.html (accessed on 22 August 2019).

Clarke, John James. 1997. Oriental Enlightenment: The Encounter Between Asian and Western Thought. New York: Routledge.

Davie, Grace. 2018. Thinking Theoretically about Religiosity, Secularity and Pluralism in the Global East. Religions 9: 337. [CrossRef]

DCLG (Department for Communities and Local Government). 2008. Face to Face and Side by Side: A Framework for Partnership in Our Multifaith Society; Wetherby: Communities and Local Government Publications.

Domke, David, and Kevin Coe. 2010. The God Strategy: How Religion Became a Political Weapon in America. Oxford: Oxford University Press.

Eade, John. 1996. Nationalism and Community, and the Islamicization of Space in London. In Making Muslim Space in North America and Europe. Edited by Metcalf Barbara Daly. Los Angeles and London: University of California Press, pp. 217-33.

Eisenstadt, Shmuel Noah. 2000. Multiple Modernities. Daedalus 129: 1-29.

Ferrari, Silvio. 2012. Law and Religion in a Secular world: A European Perspective. Ecclesiastical Law Society 14: 355-70. [CrossRef]

Fitzgerald, Timothy. 2007. Discourse on Civility and Barbarity: A Critical History of Religion and Related Categories. Oxford: Oxford University Press.

Habermas, Jürgen. 1986. The Theory of Communicative Action: Reason and Rationalization of Society. Cambridge: Polity Press, vol. 1. First published 1981.

Habermas, Jürgen. 2002. Religion and Rationality: Essays on Reason, God, and Modernity. Cambridge: MIT Press.

Habermas, Jürgen. 2008. Notes on Post-Secular Society. New Perspectives Quarterly 25: 17-29. [CrossRef]

Halafoff, Anna. 2013. The Multifaith Movement: Global Risks and Cosmopolitan Solutions. Dordrecht: Springer.

Harris, Elizabeth. 2018. Religion, Space and Conflict in Sri Lanka: Colonial and Postcolonial Perspectives. London: Routledge.

Harrison, Peter. 2015. The Territories of Science and Religion. Chicago: Chicago University Press.

Hedges, Paul, and Mohamed Imran Mohamed Taib. 2019. The Interfaith Movement in Singapore: Precarious Toleration and Embedded Autonomy. In The Interfaith Movement. Edited by John Fahy and Jan-Jonathan Bock. London: Routledge.

Hedges, Paul. 2010. Controversies in Interreligious Dialogue and the Theology of Religions. Controversies in Contextual Theology Series; London: SCM.

Hedges, Paul. 2017a. Multiple Religious Belonging after Religion: Theorising Strategic Religious Participation in a Shared Religious Landscape as a Chinese Model. Open Theology 3: 48-72. [CrossRef]

Hedges, Paul. 2017b. Towards Better Disagreement: Religion and Atheism in Dialogue. London: Jessica Kingsley Publishing.

Hedges, Paul. 2018a. Can Interreligious Dialogue Provide a New Space for Deliberative Democracy in the Public Sphere?: Philosophical Perspectives from the Examples of the UK and Singapore. Interreligious Studies and Intercultural Theology 2: 5-25.

Hedges, Paul. 2018b. Deconstructing Religion: Where we go from Here-A Hermeneutical Proposal. Exchange 47: 5-24. [CrossRef]

Hedges, Paul. forthcoming. Understanding Religion: Method and Theory for Exploring Religiously Diverse Societies. Berkeley: California University Press.

Hobson, John. 2004. The Eastern Origins of Western Civilisation. Cambridge: Cambridge University Press.

James, William. 1985. The Varieties of Religious Experience. Cambridge: Harvard University Press. First published 1902.

Khalil, Mohammad Hassan. 2017. Jihad, Radicalism, and the New Atheism. Cambridge: Cambridge University Press.

Knott, Kim. 2005. The Location of Religions: A Spatial Analysis. New York: Routledge. 
Kong, Lily, and Orlando Woods. 2016. Religion and Space: Competition, Conflict and Violence in the Contemporary World. London: Bloomsbury.

Lassman, Peter. 2004. Political Theory in an Age of Disenchantment: The Problem of Value Pluralism: Weber, Berlin, Rawls. Max Weber Studies 4: 253-71. [CrossRef]

Lefebvre, Henri. 1991. The Production of Space. Oxford: Blackwell.

Massey, Doreen. 1993. Politics and Space/Time. In Place and the Politics of Identity. Edited by Keith Michael and Pile Steve. New York: Routledge, pp. 141-61.

Masuzawa, Tomoko. 2005. The Invention of World Religions. Chicago: University of Chicago Press.

McCarthy, Kate. 2007. Interfaith Encounters in America. New Brunswick: Rutgers University Press.

Modood, Tariq. 2009. Moderate Secularism and Multiculturalism. Politics 29: 71-76. [CrossRef]

Modood, Tariq. 2016. State-Religion Connections and Multicultural Citizenship. In Religion, Secularism, and Constitutional Democracy. Edited by Jean L. Cohen and Cécile Laborde. New York: Columbia University Press, pp. 182-203.

Modood, Tariq. 2019a. Essays on Secularism and Multiculturalism. London: Rowman and Littlefield.

Modood, Tariq. 2019b. Secularism and the Governance of Religious Diversity. Singapore: Marina Mandarin Hotel.

Osborne, Samuel. 2018. Richard Dawkins accused of Islamophobia after comparing 'lovely church bells' to 'aggressive-sounding Allahu Akhbar'. The Independent. July 17. Available online: https:/www.independent.co.uk/ news/uk/home-news/richard-dawkins-allahu-akhbar-church-bells-criticism-religion-a8451141.html (accessed on 22 August 2019).

Peace, Jennifer Howe, and Or N. Rose. 2018. The Value of Interreligious Education for Religious Leaders. In Interreligious/Interfaith Studies: Defining a New Field. Edited by Eboo Patel, Jennifer Howe Peace and Noah Silverman. Boston: Beacon Press, pp. 172-82.

Portier, Philippe. 2011. Religion and Democracy in the Thought of Jürgen Habermas. Society 48: 426-32. [CrossRef]

Race, Alan. 2008. Interfaith Dialogue: Religious Accountability between Strangeness and Resonance. In Christian Approaches to Other Faiths. Edited by Paul Hedges and Alan Race. London: SCM, pp. 155-72.

Rawls, John. 1993. Political Liberalism. New York: Columbia University Press.

Sherwood, Harriet. 2017. Prince Charles accession 'could trigger debate on disestablishment'. The Guardian. December 10. Available online: https://www.theguardian.com/world/2017/dec/10/prince-charles-ascensiontime-for-debate-on-disestablishment-says-report (accessed on 22 August 2019).

Smith, Christian, and Brandon Vaidyanathan. 2011. Multiple Modernities and Religion. In The Oxford Handbook of Religious Diversity. Edited by Chad Meister. Oxford: Oxford University Press, pp. 250-65.

Stepan, Alfred. 2011. The multiple secularisms of modern Democratic and Non-Democratic Regimes. In Rethinking Secularism. Edited by Chris Calhoun, Mark Jurgensmeyer and Jonathan Van Antwerpen. Oxford: Oxford University Press, pp. 114-44.

Swamy, Muthuraj. 2016. The Problem with Interreligious Dialogue: Plurality, Conflict and Elitism in Hindu-Christian-Muslim Relations. London: Bloomsbury.

Taylor, Charles. 2004. Modern Social Imaginaries. Durham: Duke University Press.

Taylor, Charles. 2007. A Secular Age. Cambridge: The Belknap Press.

Tuan, Yi-Fu. 2008. Space and Place: The Perspective of Experience, 6th ed. Minneapolis: University of Minnesota Press. Vecchio, Kristi Del, and Noah Silverman. 2018. Learning from the Field: Six Themes from Interfaith/Interreligious Studies Curricula. In Interreligious/Interfaith Studies: Defining a New Field. Edited by Eboo Patel, Jennifer Howe Peace and Noah Silverman. Boston: Beacon Press, pp. 49-57.

Weller, Paul. 2009. How participation changes things: "Interfaith", "multifaith" and a new public imaginary. In Faith in the Public Realm: Controversies, Policies, and Practices. Edited by Adam Dinham, Robert Furbey and Vivien Lowndes. Bristol: Policy Press, pp. 63-82.

White House. n.d. The President's Interfaith and Community Service Campus Challenge. Office of Faith-Based and Neighborhood Partnerships. Available online: https://obamawhitehouse.archives.gov/administration/ eop/ofbnp/interfaithservice (accessed on 22 August 2019). 
Zaccheus, Melody. 2019. More than 250 religious organisations commit to safeguard religious harmony. The Straits Times. June 19. Available online: https://www.straitstimes.com/singapore/250-religious-groups-makecommitment-with-practical-suggestions-to-safeguard-religious (accessed on 22 August 2019).

(c)

(C) 2019 by the author. Licensee MDPI, Basel, Switzerland. This article is an open access article distributed under the terms and conditions of the Creative Commons Attribution (CC BY) license (http://creativecommons.org/licenses/by/4.0/). 